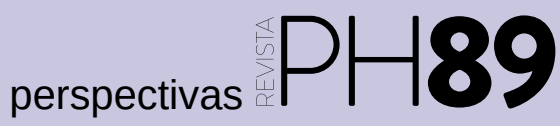

a debate Patrimonio, turismo y género. Estrategias para integrar la perspectiva de género en el patrimonio histórico

| coordinan Margarita M. Birriel Salcedo, Carmen Rísquez Cuenca

\title{
Patrimonio, género, ocio valioso y empoderamiento
}

Sandra Laguna Rodríguez | diplomada en Turismo y Trabajo Social

URL de la contribución <www.iaph.es/revistaph/index.php/revistaph/article/view/3731>

En la sala Época romana del museo municipal de Écija se exhibe la escultura de una amazona herida y se dice que su importancia es tal, que sólo hay tres en el mundo como ella. Pero si nos acercamos a la leyenda de esta guerrera, quizás lleguemos a la conclusión de que hay algunas más:

Hace miles de años Teseo, rey legendario de Atenas, se enamoró de Antíope, reina de las amazonas, a la que raptó y con la que tuvo un hijo al que llamaría Hipólito. Las amazonas en venganza por el secuestró de su reina, iniciaron la guerra contra Atenas, marcando una de las historias legendarias de Grecia. En el curso del enfrentamiento con los atenienses, las amazonas, devotas de Artemisa, con la que compartían el amor por la caza y el desinterés por los hombres, fueron derrotadas una y otra vez, en cada intento por rescatar a su reina (VILARIÑO RODRÍGUEZ, 2009).

El estado de guerra continua y la constante derrota que sufrieron las amazonas ha podido motivar que los artistas las hayan representado a lo largo de la historia como mujeres guerreras y hermosas, heroicas y constantes, pero al final siempre vencidas por los hombres, simbolizando la sumisión de la mujer al género masculino.

Esbozada esta perspectiva, estoy segura de que lectores y lectoras habrán pensado en alguna amazona herida que conozcan y se habrán preguntado a cuántas la historia ha hecho desaparecer para siempre.

La introducción de la perspectiva de género en la interpretación patrimonial debería considerarse una obligación para todos los gestores y gestoras culturales. Reescribir la historia haciendo visibles a las mujeres, sus logros, su interpretación del mundo y su función en él, es un camino hacia el empoderamiento femenino y

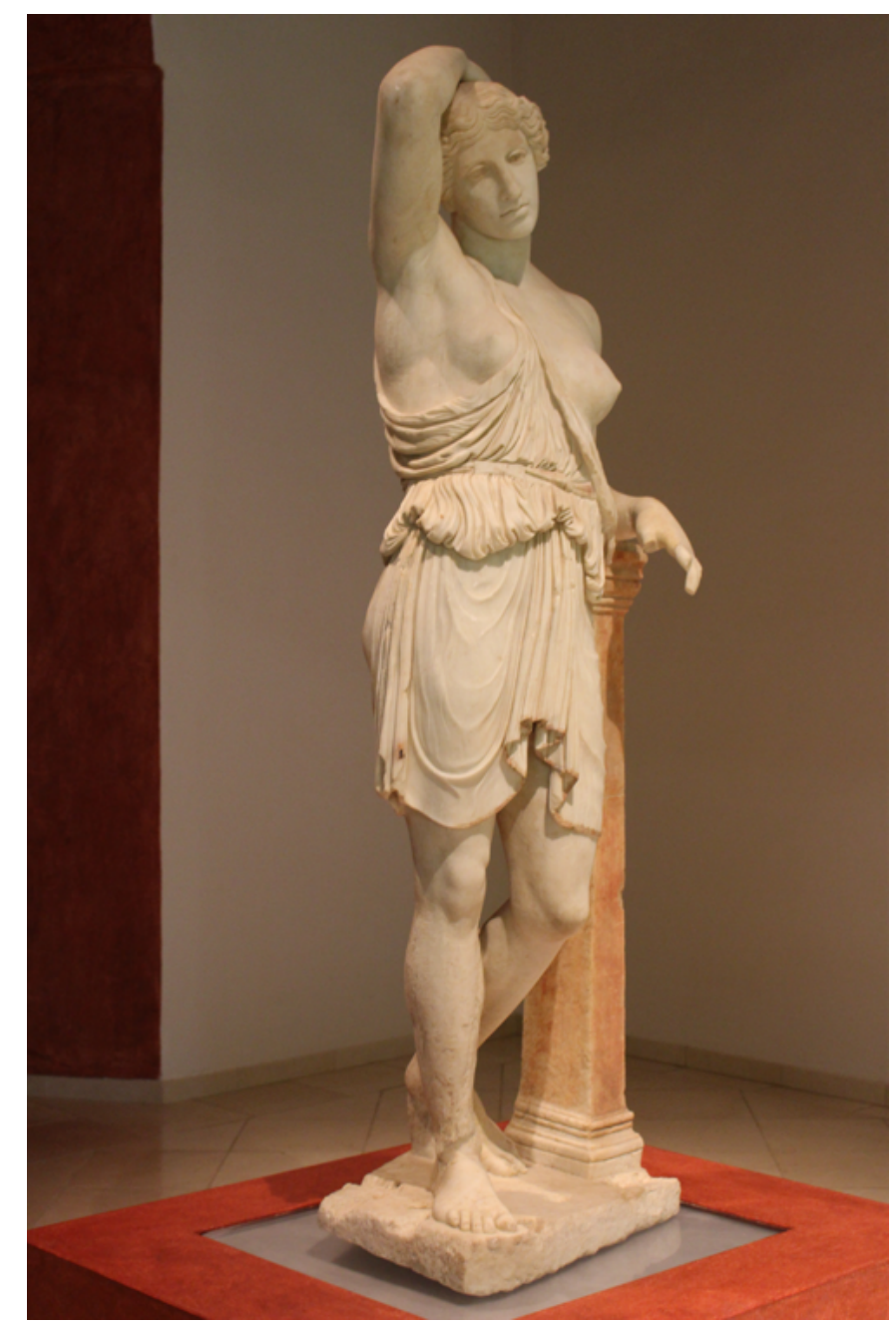

Amazona herida del museo municipal de Écija | foto Ángela Lora

es incluso una fórmula de intervención social, que podría generar un cambio y eliminar del discurso histórico la desigualdad que supone la invisibilidad de las mujeres. La historia está para que aprendamos de ella y si en la narración del patrimonio seguimos reproduciendo los mismos discursos en los que sólo aparecen hombres, no estamos aprendiendo nada. 
a debate Patrimonio, turismo y género. Estrategias para integrar la perspectiva de género en el patrimonio histórico

| coordinan Margarita M. Birriel Salcedo, Carmen Rísquez Cuenca

Por otro lado, en esta sinergia de patrimonio, género y turismo sería aconsejable contar con la opinión de profesionales de la intervención social para que ayudaran a enriquecer los distintos discursos que se reproducen en la interpretación del patrimonio. De tal forma que el acercamiento al patrimonio desde la perspectiva de género se trasformara en una actividad empoderadora ofreciendo una visión más amplia de los roles de género. Incluso los profesionales de la acción social podrían aprovechar estas nuevas interpretaciones como herramientas en las dinámicas dirigidas a mujeres.

Y si nos imaginamos que esta interpretación patrimonial se desarrolla en el ámbito de una actividad de ocio o tiempo libre (como podría ser una visita guiada en el museo desde una nueva perspectiva de género), además de lo mencionado anteriormente, sería ocio valioso que, tal y como define Cuenca Cabeza: "es la afirmación de un ocio con valores positivos para las personas y las comunidades, un ocio basado en el reconocimiento de la importancia de las experiencias satisfactorias y su potencial de desarrollo social. El adjetivo 'valioso' enfatiza aquí el valor social beneficioso que se reconoce en la práctica de determinados ocios, así como su potencial de desarrollo humano, lo que no excluye otros tipos de desarrollo, como pudiera ser el económico" (2014: 87).

Podemos entender, tras la definición de este autor, que ocio valioso es un tipo de ocio humanista en el que se pone en valor la dimensión psicosocial del disfrute. Y eso es precisamente lo que proponermos, actividades interpretativas que conlleven un desarrollo psicosocial, por lo que puedan enmarcarse dentro de la categoría de ocio valioso.

La tarea no es nada fácil, pero afortunadamente las mujeres de nuestras historias tenían un poco de "brujas" (en el sentido de mujeres sabias que parecían presentir lo que iba a suceder), y podemos intuir que fueron dejando algunas huellas que nos pueden ayudar a imbricar las dos mitades de la historia (femenina y masculina). Ejemplo de estas huellas femeninas pueden ser las propias amazonas, los nombres de aquellas mujeres que se salieron de la norma, o las historias de vida de muchas mujeres que todas y todos tenemos cerca.

Hay bastantes huellas, sólo tenemos que mirar con atención, y aunque sea un trabajo difícil es también un trabajo emocionante $y$, como se ha dicho, necesario. Desde mi óptica una de las mejores oportunidades de esta nueva reinterpretación para el turismo y el ocio en general es la creación de visitas guiadas basadas en el papel de la mujer en la propia localidad, para hacerlo visible, y para que sirva, no sólo como recurso turístico, sino como herramienta empoderadora de la mujer, convirtiéndolo en ocio valioso.

\section{BIBLIOGRAFÍA}

- CABEZA CUENCA, M. (2014) Ocio valioso [libro-e]. sl: Universidad de Deusto, 2014

- VILARIÑO RODRíGUEZ, J. J. (2009) Heracles y los pueblos arqueros de la antigüedad. Studia Historica: Historia Antigua, Salamanca, vol. 27, pp. 31-48, febrero 2009 <http://revistas. usal.es/index.php/0213-2052/article/view/7706> [Consulta: 20/ 04/2016] 